\section{John Sutton Pippard}

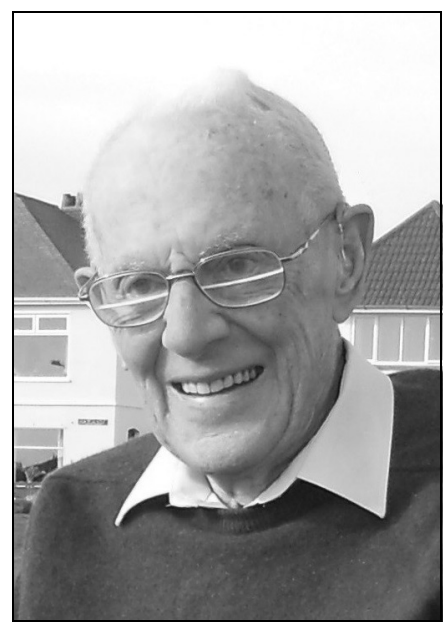

Formerly consultant psychiatrist at Claybury Hospital, fellow of the Royal College of Psychiatrists

John Pippard was a consultant psychiatrist at Claybury Hospital, Essex. Born on 20 May 1919, he died from pneumonia after a fall at home on 21

December 2012.

John was the elder son of Olive and A.J.S. (Sutton) Pippard FRS who was Professor of Civil Engi-

neering at Imperial College London. He trained to be a doctor at Cambridge and the London Hospital, qualifying in 1942 and then gaining MRCP in the same year. After completing his house jobs at the London Hospital, he served in the Royal Army Medical Corps in north Africa and Italy, before taking charge of the Medical Division of the British General Hospital in Klagenfurt, Austria. There he met and married Kathleen, also a doctor, in 1947. John trained initially to become a physician at the London Hospital but then changed to psychiatry, training at the London, Maudsley and St George's hospitals. During his training he was also a Fellow of Corpus Christi College in Cambridge where he supervised students in physiology (19471950). His MD research (1955), for which he was awarded the Copeman medal by Corpus Christi, examined factors that influenced the likelihood of beneficial or adverse effects in patients after modified leucotomy.

He became a consultant psychiatrist at Claybury Hospital in 1955, where, encouraged by the Medical Superintendent Stuart Harris, he and Dennis Martin and later Elisabeth Shoenberg and Derek Kelsey were to transform a well-run traditional mental hospital into a pioneering therapeutic community. This was the first time such an experiment involving a large mental hospital had been made in the UK. This 'Adventure in Psychiatry' (also a book of the same title published by Martin in 1963) led to a revolution in the management of acutely ill patients, who now became active participants in their own treatment. Its non-hierarchical group approach, involving all the staff and patients in therapeutic decision-making, appealed to John's democratic spirit and his deeply held Quaker beliefs.

John's approach to psychiatry was eclectic but very much inspired by psychodynamic thinking. He was an effective group therapist, exercising his skills with acutely disturbed and psychotic patients where his compassionate understanding and humane approach, as well as his acute insights, brought relief to patients and inspired generations of trainees, such as ourselves. Many years after retirement patients continued to write to him expressing their gratitude for his help, and he responded comfortingly to all their letters in his very legible and elegant script. In a letter by John to one of us (L.F.) in 2008 about a paper and book on therapeutic groups in acute units (written by L.F.), John's modesty, as well as his natural talents, shone through: 'You said I should have written about it myself and I acknowledge the dereliction. The conditions I was working in were, as you know, very different from what you have to cope with. I had no training in psychotherapy and flew by the seat of my pants. I did not find reading about psychotherapy or groups particularly helpful - if anything it interfered in my spontaneity! As I read your paper I became painfully aware of many of my shortcomings and missed opportunities. However, I did not try and teach systematically but hoped that staff and patients would absorb something useful from participating in the community. Claybury in the 50 s and $60 \mathrm{~s}$ was a great place to work and evidently involved and inspired a great many people who took their experience all over the world. I'm glad I was part of the Adventure in Psychiatry.'

At the end of his time at Claybury he worked briefly with patients with intellectual disability at Leytonstone House. He retired in 1979. He was made FRCP in 1966 and became FRCPsych (Foundation) in 1972. After his retirement he became a research fellow for the Royal College of Psychiatrists. There he made an important national survey of the use of ECT in the UK, published in 1981 as 'Electro-convulsive treatment in Great Britain'. This report highlighted inadequate practice of ECT in many places and led to major changes that John documented in a subsequent audit in 1991. He was also a Commissioner for the Mental Health Act Commission (1983-1986)

In retirement he stayed very active, enjoying looking after the large garden of his beautiful Regency house in Woodford, where he and his wife happily entertained friends and colleagues. He was a keen amateur musician and continued to play the cello well on into his $80 \mathrm{~s}$. John had a cheerful and optimistic disposition and when for reasons of physical frailty he had to move into a residential home he quickly adapted to this new environment: he spent the last 2 years of his life contentedly at Quaker House, where he was near his daughter and where he soon made new friends. He was predeceased by Kathleen, who was a family planning doctor, in 2005 and he leaves four children and nine grandchildren, of whom he was very proud.

doi: $10.1192 /$ pb.bp. 113.043406

Leonard Fagin \& Peter Shoenberg

\section{Norman Kreitman}

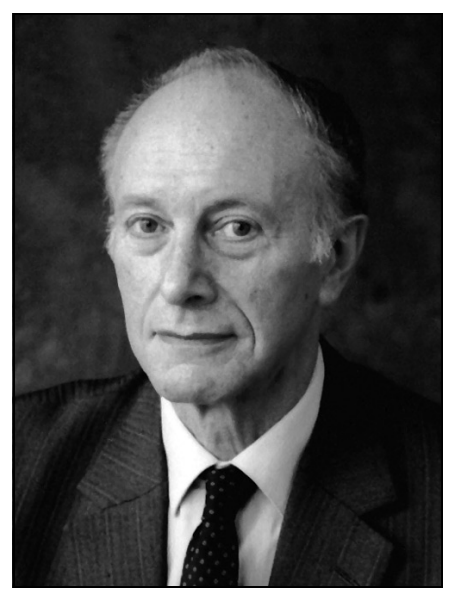

Formerly psychiatrist and suicide expert

Norman Kreitman was an urbane and cultured man; a psychiatrist, philosopher and poet. He strode the world stage as a suicide researcher, winning the Distinguished Research Award from the American Society for Suicidology in 1987. At this time he was Director of the Medical Research Council (MRC) Unit for Epidemiological Psychiatry in Edinburgh, where he oversaw research into suicide, depression in women and alcohol consumption. He is the person who coined the term 'parasuicide', a recognition, 
not acknowledged at the time, that most episodes of self-harm are not attempts at suicide.

A Londoner by birth, Norman qualified as a doctor in 1950 from the University of London. He worked in medicine at the Metropolitan Hospital in London and spent time as a researcher at the Forlanni Institute in Rome, Italy, before finally deciding on a career in psychiatry, training at the Maudsley Hospital in London. In 1971, he moved to Edinburgh, where he lived for the rest of his life. He was Foundation Editor of Social Psychiatry during this time. He retired from the MRC Unit when it closed in 1990.

Unlike many academics who, on retirement, continue in other academic or clinical posts, Norman put psychiatry behind him and with great ease. Instead, he turned to his lifelong interests in poetry and philosophy. He immersed himself in this creative work, publishing four volumes of poetry and a number of academic papers in philosophy journals. He was a very keen fisherman and remained so until shortly before his death. He took part in the Edinburgh International Festival with great gusto and would be seen at morning concerts in various venues, while the Usher Hall was his evening haunt. Conversation with Norman was always stimulating but he too was a wonderful listener, perhaps influenced by his interest in psychotherapy.

Norman was a willing supervisor to those of us whom he mentored, yet he never reprimanded or chastised. His capacity for clear thinking around methodological problems in research was a tool he used to great effect when guiding us in our projects. Even before it was acceptable in those aspiring to high academia, he understood that some of his researchers should, at times, work from home if family required this.

His wife Susan was his great companion and they were warm hosts to a stream of doctors and other mental health researchers working in the MRC Unit, whom they entertained in their home. As the years went by, Norman and Susan became very regular hosts to my family, with Norman advising my son as he wrote his Master's dissertation. Two of Norman's papers, published in Metaphilosophy in 2011, are cited in it.

The onset of cancer a number of years ago did not curtail Norman's cultural activities and he continued to attend concerts and to write. Norman died at his home on 15 December 2012 at the age of 85 surrounded by his loving family. He is survived by his wife Susan, two children, Julia and Matthew, and four grandchildren. He will be deeply missed by all of us who had the great privilege of knowing him.

And tomorrow night the forms will return As always, when they and this ageing man Honour once more the cherished youth Who strode through halls, could run upstairs. ${ }^{1}$

1 Kreitman N. Casanova's 72nd Birthday. In Dancing in the Dark: New and Selected Poems. Norman Kreitman, 2010.

Patricia Casey 